\title{
PENGARUH PEMBERIAN AIR REBUSAN KACANG HIJAU TERHADAP PENINGKATAN KADAR HEMOGLOBIN PADA PEKERJA BAGIAN KANTOR DI RS.GRANDMED
}

Jul Asdar Putra Samura1, Delita Br Panjaitan², Raisha Octavariny ${ }^{3}$, Sri Melda $\mathrm{Br}$ Bangun $^{4}$, Eka Wulandari ${ }^{5}$

Program Studi Kesehatan Masyarakat Fakultas Kesehatan Masyarakat

Institut Kesehatan Medistra Lubuk Pakam

Jl. Sudirman No.38 Lubuk Pakam Kec. Lubuk Pakam Kab. Deli Serdang,

Sumatera Utara

Email: Gheteks@gmail.com

\begin{abstract}
Hemoglobin is a protein that is rich in iron. The function of $\mathrm{Hb}$ in the blood is to carry oxygen to the lungs, to the tissues and to carbon dioxide. Efforts to increase hemoglobin levels are related to the intake of foods containing iron, one of which is the provision of green bean cooking water. The purpose this study was determine the effect of giving mung bean boiled water to an increase in hemoglobin levels in office workers at Rs.Grandmed Lubuk Pakam. This research design with one group pre test-post test. The population in this study were employees of Rs.Grandmed. The number of research samples were 48 workers for the total sampling. Data analysis using paired t-test. The results showed that the HB level of workers before giving green bean cooking water was not normal, namely $39(81.3 \%)$ respondents with an average of 1.81 . The $H B$ levels of workers after giving green bean boiled water were all normal HB categories, namely as many as $48(100 \%)$ respondents with an average of 1.00 . Data analysis using pre-test and post-test giving green bean boiled water in the experimental group showed results where the $p$ value was 0.000 , the value was $0.000<0.05$, so it could be said that there was a significant difference between. hypothesis is accepted. The conclusion of this study is that there is an effect of giving mung bean boiled water to an increase in hemoglobin levels in office workers at the GrandMed Lubuk Pakam Hospitall. It is hoped that the hospital leadership will educate the workers that green bean cooking water can be used as an alternative to increasing hemoglobin levels.
\end{abstract}

Keyword : Hemoglobin, green beans cooking water 


\section{PENDAHULUAN}

Anemia ialah suatu permasalah kesehatan masyarakat terbesar di dunia terutama bagi kelompok Wanita Usia Subur (WUS). Berdasarkan data dari World Health Organization (WHO) 2011, ditemukan ada 1,62 miliar orang atau sekitar $24,8 \%$ pernah mengalami gangguan anemia, dengan prevalensi usia wanita yang produktif sebesar $30,2 \%$. penyakit ini biasanya terjadi pada WUS yang bisa menimbulkan gelaja seperti lelah, kurang bersemangat, penurunan kapasitas dan produktivitas kerja. Wanita penderita anemia menjadi kurang produktif bekerja dibanding wanita tanpa anemia karena pada penderita anemia mengalami penurunan kapasitas transportasi oksigen dan terganggunya fungsi otot dikaitkan dengan defisit zat besi (Fe) (Retnorini, 2017).

Hemoglobin merupakan protein yang tersusun secara simpel yakni dimana globin dan radikal prostetik yang berwarna, dan disebut heme. Dalam protein ini terdapat bercak-bercak darah merah dan dapat dipisahkan dari pada itu dengan cara pemusingan. Dalam hal ini protein akan membawa oksigen dalam darah. Terdapat $150 \mathrm{gr}$ kandungan hemoglobin yang terkandung dalam setiap liter darah. (Riri, 2019).

Sel-sel darah akan memfokuskan hemoglobin dalam bentuk cairan kurang lebih $34 \mathrm{gm} / \mathrm{dl}$ sel, hal ini tidak akan terjadinya peningkatan, sebab merupakan batas dari metabolik dalam sistem mekanisme pembentukan hemoglobin sel. Selanjutnya pada orang normal persentase hemoglobin hampir selalu mendekati maksimum dalam setiap sel. apabila pembentukan hemoglobin didalam sumsum tulang berkurang, maka kandungan dari hemoglobin yang ada didalam darah merah akan menurun. Apabila hematrokit atau jumlah persentasi sel dalam darah itu normalnya 40 sampai 50 $\%$ dan jumlah hemoglobin dalam masing-masing sel nilainya normal, maka seluruh darah seorang pria ratarata mengandung $16 \mathrm{gram} / \mathrm{dl}$ hemoglobin, dan pada wanita rata-rata $14 \mathrm{gram} / \mathrm{dl}$.

Cara yang efektif untuk meningkatkan kadar hemoglobin pada darah adalah mengkonsumsi air rebusan kacang hijau setiap hari kurang lebi 2 gelas/hari yang sama jika mengkonsumsi $50 \%$ kebutuhan zat besi setiap hari adalah $18 \mathrm{mg}$ kacag hijau adalah jenis tumbuhan kacang-kangan yang mudah ditemui di indonesia. Kandungan karbohidrat dan serat yang baik dalam kacang hijau. Kandungan lemak yang terdapat pada kacang hijau ini adalah 0,7-1 $\mathrm{gr} / \mathrm{kg}$ sehingga sangat baik di konsumsi oleh orang yang mengalami anemia atau kekurangan darah (Umi, 2017).

Kantor rumah sakit grandmed memiliki bagian nya masing-masing, seperti ruang akutansi, honor dokter, ruang pengkodingan, rekam medik dan klaim bpjs. Pada bagian klaim bpjs tugas nya mengklaim biaya pasien rawat inap dan rawat jalan. Serta mengkode diagnosa pasien rawat jalan. Memberkasi berkas pasien rawat jalan dan rawat inap, seperti mengurutkan dan menyusun berkas pasien kemudian di scan dan di arsipkan ke komputer.

Berdasarkan survei awal yang dilakukan peneliti dengan metode wawancara bahwasanya pekerja wanita dibagian kantor sering mengeluhkan lebih cepat merasakan haus, kelelahan disertai pusing ketika sedang bekerja. Bisa saja itu diakibatkan karena kondisi 
mereka yang bekerja lebih dari 8 jam yang memungkinkan mereka cepat merasa lelah karena kurang istirahat. Konsumsi zat besi yang rendah dalam pola makannya sehari-hari juga dapat memicu kadar hemoglobin menjadi rendah. Haid juga mengakibatkan kehilangan sejumlah darah dari tubuh yang ditandai dengan penurunan kadar hemoglobin. Hal ini akan menyebabkan gejala anemia. Dari hasil observasi sebagian pekerja wanita mengeluh sakit saat menstruasi, menjadi malas beraktivitas, dan mereka belum begitu paham tentang perbedaan kadar hemoglobin saat menstruasi dan setelah menstruasi.

Oleh karena itu berdasarkan yang tertera diatas, saya sebagai peneliti tertarik untuk mencoba memberikan sesuatu yang dapat meningkatkan kadar hemoglobin para pekerja. Maka dari itu saya akan melakukan penelitian tentang "Pengaruh Pemberian Air Rebusan Kacang Hijau Terhadap Peningkatan Kadar Hemoglobin pada Pekerja Bagian Kantor Rs.Grandmed Lubuk Pakam

\section{METODE PENELITIAN}

Jenis penelitian ini merupakan penelitian kuantitatif yang bersifat eksperimen dengan pendekatan quasi eksperimen dengan desain pre-test dan post-test yaitu suatu penelitian yang bertujuan untuk melihat adanya pengaruh pemberian air rebusan kacang hijau terhadap peningkatan kadar hemoglobin pada pekerja di rumah sakit grandmed sebelum dan sesudah diberikan perlakuan. Variabel independen dalam penelitian ini adalah pemberian air rebusan kacang hijau dan variabel dependen penelitian ini adalah kadar hemoglobin. Populasi pada penelitian ini adalah seluruh pekerja kantor Rumah sakit Grandmed Lubuk Pakam. Berdasarkan data yang diperoleh jumlah pegawai kantor 94 orang.Teknik pengambilan sampel pada penelitian ini adalah purposive sampling. Karena jumlah populasi yang kurang dari 94 seluruh populasi dijadikan sampel penelitian. Sampel yang diambil dalam penelitian ini adalah 48 orang.Pengumpulan data dengan menggunakan data primer dan data sekunder. Data primer mengenai karakteristik individu seperti nama, umur, dan masa kerja, serta pekerja yang menderita anemia diperoleh melalui wawancara langsung kepada responden dengan lembar observasi yang sudah persiapkan.Data sekunder dalam penelitian ini diperoleh dari literatur ilmiah dan penelitian-penelitian terdahulu yang berkaitan dengan sikap kerja dan peningkatan kadar hemoglobin pada pekerja d Rrumah sakit Granmed.

Data dianalisis untuk perhitungan bivariat pada penelitian ini menggunakan Uji pairedt-test dengan ketentuan $\mathrm{a} \leq$ 0,05 . Pengujian ini dilakukan untuk membuktikan hipotesa pengaruh pemberian air rebusan kacang hijau terhadap peningkatan kadar hemoglobin pada pekerja bagian kantor di Rs. Grandmed Lubuk Pakam sebelum dan sesudah pemberian intervensi pada para pekerja. 


\section{HASIL}

Univariat

Tabel 1 Distribusi Frekuensi Responden Berdasarkan Usia Pada Pekerjabagian kantor di Rs.Grandmed

\begin{tabular}{|c|c|c|c|}
\hline No & Usia & $\begin{array}{l}\text { Frekuens } \\
\text { i }\end{array}$ & $\begin{array}{l}\text { Persentase } \\
\%\end{array}$ \\
\hline 1 & $\begin{array}{l}\text { 20- } \\
24 \text { Tahu } \\
\text { n }\end{array}$ & 8 & $16,7 \%$ \\
\hline 2 & $\begin{array}{l}\text { 25- } \\
\text { 29Tahu } \\
\text { n }\end{array}$ & 33 & $68,8 \%$ \\
\hline 3 & $\begin{array}{l}\text { 30- } \\
\text { 34Tahu } \\
n\end{array}$ & 6 & $12,5 \%$ \\
\hline 4 & $\begin{array}{l}\text { 35-39 } \\
\text { Tahun }\end{array}$ & 1 & $2,1 \%$ \\
\hline $\begin{array}{l}\text { Tota } \\
\text { I }\end{array}$ & & 48 & $100 \%$ \\
\hline
\end{tabular}

diketahui bahwa rentang usia yang terbesar adalah 25 - 29 tahun dengan presentase $68,8 \%$, sedangkan yang terkecil pada rentang usia 35 - 39 tahun dengan presentase $2,1 \%$.

Tabel 2 Distribusi Frekuensi Responden Berdasarkan Pendidikan pada Pekerja bagian kantor di Rs.Grandmed

\begin{tabular}{lccl}
\hline No & $\begin{array}{l}\text { Pendidik } \\
\text { an } \\
\text { Terakhir }\end{array}$ & $\begin{array}{c}\text { Frekuen } \\
\text { si }\end{array}$ & $\begin{array}{l}\text { Persentase } \\
\%\end{array}$ \\
\hline 1 & S1 & 47 & $97,9 \%$ \\
2 & S2 & 1 & $2,1 \%$ \\
Tot & & 48 & $100 \%$ \\
al & & &
\end{tabular}

Berdasarkan tabel 2 dapat diketahui bahwa rentang pendidikan yang terbesar adalah S1 dengan presentase 97,9 \%, sedangkan yang terkecil pada rentang pendidikan S2 dengan presentase 2,1\%.

Tabel 3. Distribusi Frekuensi Responden Berdasarkan Tinggi Badan Pada Pekerja bagian kantor di Rs.Grandmed

\begin{tabular}{lccc}
\hline No & $\begin{array}{c}\text { Tinggi } \\
\text { Badan }\end{array}$ & Frekuensi & $\begin{array}{c}\text { Persentase } \\
\%\end{array}$ \\
\hline 1 & $140-$ & 12 & $25,0 \%$ \\
& 150 & & \\
& $\mathrm{Cm}$ & & \\
\hline
\end{tabular}

\begin{tabular}{llll}
\hline 2 & $151-$ & 36 & $75,0 \%$ \\
& 170 & & \\
& $\mathrm{Cm}$ & & \\
Total & & 48 & $100 \%$ \\
\hline
\end{tabular}

Berdasarkan Tabel 3 dapat diketahui bahwa tinggi badan yang terbesar adalah 151-170 Cm dengan persentase $75,0 \%$, sedangkan yang terkecil pada rentang tinggi badan 140$150 \mathrm{Cm}$ dengan persentase $25,0 \%$.

Tabel 4 Distribusi Frekuensi Responden Berdasarkan Berat Badan pada Pekerja bagian kantor di Rs.Grandmed

\begin{tabular}{lccc}
\hline No & $\begin{array}{c}\text { Berat } \\
\text { Badan }\end{array}$ & Frekuensi & $\begin{array}{c}\text { Persentase } \\
\%\end{array}$ \\
\hline 1 & $\begin{array}{c}40-50 \\
\mathrm{Kg}\end{array}$ & 10 & $20,8 \%$ \\
2 & $51-60$ & 32 & $66,7 \%$ \\
& $\mathrm{Kg}$ & & $12,5 \%$ \\
3 & $\begin{array}{c}61-70 \\
\mathrm{Kg}\end{array}$ & 6 & \\
Total & & 48 & $100 \%$ \\
\hline
\end{tabular}

Berdasarkan Tabel 4 dapat diketahui bahwa berat badan yang terbesar adalah $51-60 \mathrm{Kg}$ dengan persentase $66,7 \%$, sedangkan yang terkecil pada berat badan $61-70 \mathrm{Kg}$ dengan persentase $12,5 \mathrm{Kg}$.

\section{Bivariat}

Tabel 5 Uji perbedaan sebelum dan sesudah diberikan rebusan air kacang hijau

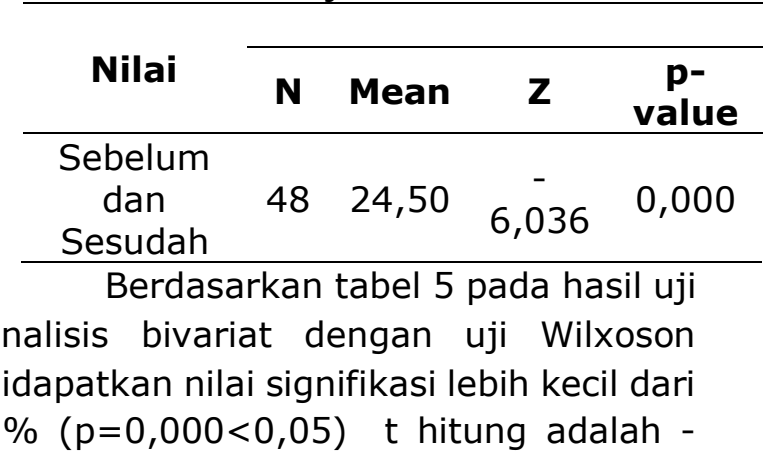


6,036 hal ini menunjukkan bahwa ada perbedaan rata-rata sebelum diberikan air rebusan kacang hijau dengan setelah diberikan air rebusan kacang hijau. Ditarik kesimpulan penelitian ini adalah Ada Pengaruh Pemberian Air Rebusan Kacang Hijau Terhadap Peningkatan Kadar Hemoglobin Pada Pekerja Bagian Kantor di Rs. Grandmed Lubuk Pakam.

\section{PEMBAHASAN}

Berdasarkan hasil yang didapat peneliti diketahui bahwa sebelum diberikan air rebusan kacang hijau terdapat hb yang paling banyak adalah hb tidak normal yaitu sebanyak 39 ( 81,3 $\%$ ) responden dengan rata-rata yang di dapat adalah 1,81. Berdasarkan hasil yang didapat peneliti diketahui bahwa sebelum diberi air rebusan kacang hijau sedangkan setelah pemberian air rebusan kacang hijau adalah 1,81 dan rata rata setelah pemberian air rebusan kacang hijau 1,00 yang artinya ada perbedaan rata-rata sebelum dilakukan diberikan air rebusan kacang hijau dengan setelah diberikan air rebusan kacang hijau.

Berdasarkan tabel diatas menunjukkan hasil nilai sig Shapiro-Wilk sebesar 0,000 $(p<0,05)$. Sehingga kesimpulan uji normalitas menyatakan bahwa data tidak berdistribusi normal. Karena data tidak berdistribusi normal sehingga penelitian dilanjutkan dengan menggunakan statistik Non Parametrik yaitu menggunakan uji Wilxocon.

Berdasarkan hasil analisis dengan uji Wilxoson didapatkan nilai signifikasi lebih kecil dari $5 \%(p=0,000<0,05) \quad t$ hitung adalah $-6,036$ hal ini menunjukkan bahwa ada perbedaan rata-rata sebelum diberikan air rebusan kacang hijau dengan setelah diberikan air rebusan kacang hijau. Ditarik kesimpulan penelitian ini adalah Ada Pengaruh Pemberian Air Rebusan Kacang Hijau Terhadap Peningkatan Kadar Hemoglobi Pada Pekerja Bagian Kantor di Rs. Grandmed Lubuk Pakam

\section{KESIMPULAN}

Berdasarkan hasil penelitian dan pembahasan diatas dapat ditarik kesimpulan sebagai berikut :

1. Kadar hb sebelum diberikan air rebusan kacang hijau didapatkan hasil lebih banyak mempunyai kadar hb tidak normal yaitu sebanyak 39 ( $81,3 \%$ ) responden dengan rata-rata yang didapat adalah 1,81 dengan standar devisiasi (SD) 0,394.

2. Kadar hb setelah diberikan air rebusan kacang hijau didapatkan bahwa kategori hb semua normal yaitu sebanyak $48 \quad(100 \%)$ responden dengan rata-rata yang didapat adalah 1,00 dengan standart devisiasi (SD) 0,000.

3. Dengan menggunakan uji Wilcoxon diperoleh nilai $p=0,000 \quad(p<$ $0,005)$. Dengan demikian dapat disimpulkan bahwa " Ada Pengaruh Pemberian Air Rebusan Kacang Hijau Terhadap Peningkatan Kadar Hb Pada Pekerja Bagian Kantor Di Rs.Grandmed Lubuk Pakam".

\section{DAFTAR PUSTAKA}

Faridah Umi.2017. Pemberian Kacang Hijau Sebagai Upaya Peningkatan Kadar Hemoglobin Pada Remaja

Gizi Dengan Produktivitas Kerja Wanita Di Bagian Percetakan Dan Pengemasan Si Ud X Sidoarjo 
Retnorini.2017. Pengaruh Pemberian Tablet Fe Dan Sari Kacang Hijau Terhadap Kadar Hemoglobin Pada Ibu Hamil.

Nuraeni Riri,2019.Peningkatan Kadar Hemoglobin Melalui Pemeriksaan Dan Pemberian Tablet Fe Terhadap Remaja Yang Mengalami Anemia Melalui Gerakan Amirul Amalia.2016. Efektivitas Minuman Kacang Hijau Terhadap Peningkatan Kadar Hemoglobin.

WHO. 2011. Prevention Of Deficiency Anaemia In Adolescents Role Of Weekly Iron And Folic Acid Supplementation Iron.http://apps.searo.who.int/ PDS_DOCS/B4770. 